Article

\title{
Optimization of Acid Leaching of Rare-Earth Elements from Mongolian Apatite-Based Ore
}

\author{
Rina Kim ${ }^{1}$, Heechan Cho ${ }^{1, *}$, Kenneth N. Han ${ }^{2}$, Kihong Kim ${ }^{1}$ and Myoungwook Mun ${ }^{1}$ \\ 1 Department of Energy Resources Engineering, Seoul National University, Seoul 08826, Korea; \\ oneplus8@snu.ac.kr (R.K.); kryd81@nate.com (K.K.); youry19@snu.ac.kr (M.M.) \\ 2 Department of Materials and Metallurgical Engineering, South Dakota School of Mines and Technology, \\ Rapid City, SD 57701-3995, USA; kennethhydro@gmail.com \\ * Correspondence: hccho@snu.ac.kr; Tel.: +82-2-880-8271
}

Academic Editor: William Skinner

Received: 31 March 2016; Accepted: 24 June 2016; Published: 30 June 2016

\begin{abstract}
Optimization of the acid leaching process for Mongolian apatite-based ore containing rare-earth elements (REEs) was studied. The ore contained approximately $10 \%$ of REEs as total rare earth oxides, and the major impurities were $\mathrm{Ca}(33 \%$ as $\mathrm{CaO})$ and $\mathrm{Fe}\left(23 \%\right.$ as $\left.\mathrm{Fe}_{2} \mathrm{O}_{3}\right)$. Fe bearing minerals could be removed by passing the sample through a wet high-intensity magnetic separator before leaching. After magnetic separation, basic leaching tests were conducted to investigate the influence of the acid type and concentration, temperature, and the $\mathrm{pH}$ on the REE leaching level and kinetics. Hydrochloric acid was found to be the most effective leaching agent, leaching more than $90 \%$ of REEs in an hour. However, the concentrations of $\mathrm{Ca}$ ions in the leachate were also high, which would complicate recovery of the REEs. Therefore, to reduce the amount of $\mathrm{Ca}$ ions in the leachate, a two-stage leaching procedure was attempted. In stage 1, the sample was preleached using $1.0 \mathrm{M}$ hydrochloric acid to dissolve Ca. In stage 2, the solid residue of stage 1 was leached using $2.0 \mathrm{M}$ hydrochloric acid to dissolve REEs. Consequently, this two-stage leaching significantly reduced the Ca concentration in the final leachate without affecting the leaching levels of REEs.
\end{abstract}

Keywords: rare-earth element; acid leaching; apatite; magnetic separation; two-stage leaching; Ca removal

\section{Introduction}

With increasing demand for rare-earth elements (REEs) and the corresponding recent surge in their prices, many countries have begun to reevaluate old rare-earth mining prospects and explore new ones. According to a 2009 estimate by the U.S. Geological Survey, Mongolia has 31 million tonnes of rare-earth reserves (approximately $17 \%$ of the world's total), exceeded only by China [1]. In light of Chinese restrictions on REE exportation, Mongolia has become a leading contender in the current rush for REE resources [1]. At present, Mongolia plans to increase its transportation infrastructure to ship mineral resources to Russia and the Far East [1]. Therefore, Mongolian resources potentially represent a major supply of REEs for Korea.

The REE ore deposit currently under investigation is located in southern Mongolia and contains over 300,000 $t$ of rare-earth oxides (REOs) as combined REOs according to a recent exploration campaign [2]. The average REO grade in this area is $1.36 \%$ but reaches $6.15 \%$ in a newly discovered high-grade zone. This deposit consists of sheet-like magnetite-apatite ore bodies [3].

REE ores are usually processed in two steps: physical concentration and leaching. The first step typically includes crushing the ore and physically separating the REOs from the ore. This separation process dramatically increases the percentage of REOs in the working material but is successful only if the REEs are largely concentrated in a single mineral phase such as a form of bastnäsite $\left(\mathrm{REECO}_{3} \mathrm{~F}\right)$ 
or monazite $\left(\mathrm{REEPO}_{4}\right)$ [4]. Unfortunately, this is not the case for the REE ore under investigation, which contains primarily apatite $\left[\mathrm{Ca}_{10}\left(\mathrm{PO}_{4}\right)_{6}(\mathrm{OH}, \mathrm{F}, \mathrm{Cl})_{2}\right]$ as the major source mineral. REEs in apatite usually occur as ionic substitutions for $\mathrm{Ca}$ within the crystal lattice rather than in discrete mineral form [5-7]. Intuitively, it is possible to obtain REE concentrates by selective separation of REE-bearing apatite from the ore. Froth flotation is a common process applied to phosphate ores. Consequently, various flotation tests were conducted in an attempt to obtain REE concentrates. However, the results were not satisfactory, yielding either a low recovery and/or little REE enrichment in the concentrates. Other physical concentration methods such as gravity separation and magnetic separation were also found to be ineffective in concentrating REEs, but magnetic separation showed positive effects on impurity removal.

The extraction of REEs from ore usually involves decomposition with acidic or alkaline reagents. In the acid route, acid baking is commonly used for the major REE minerals including monazite, bastnäsite, and xenotime. The treatment involves mixing REE concentrates with sulfuric acid followed by baking at around $200^{\circ} \mathrm{C}$. The resulting cake is leached with water to dissolve REEs. Alkaline digestion is typically used for monazite. The ore is decomposed with $\mathrm{NaOH}$ to produce rare earth hydroxides. The resulting products are then leached using hydrochloric acid to dissolve REEs. In addition, direct decomposition by $\mathrm{HCl}$ is another common method used for carbonate minerals such as bastnäsite.

Several studies have examined the acid leaching of REE apatite [8-12]. It was reported that apatite leached well in hydrochloric or nitric acid $[8,10,11]$, but it was very difficult to attack with sulfuric acid unless the concentration and/or temperature were very high $[8,10,12]$. However, owing to the complex metallurgy of REEs, there is no standard process for leaching REE-bearing minerals. The choice of decomposition method depends on the mineralogy of the REE-containing phases as well as other non-REE minerals present in the ore that often affect the effectiveness of the leaching process.

This study investigates the leaching behavior of a Mongolian REE ore in response to various acids. To reduce impurities in the leachate, pre-removal of Fe by magnetic separation and a two-stage leaching process for selective removal of $\mathrm{Ca}$ were studied. The specific objectives were to examine the mineralogical characteristics of the sample, determine the effects of the acid type and concentration, temperature, and the $\mathrm{pH}$ on the leaching efficiency, and assess the optimum conditions of the leaching process for this apatite-based ore.

\section{Materials and Methods}

\subsection{Mineralogical Characteristics of the Sample}

The sample was collected from the southern region of Mongolia. Previous studies reported that the REE deposit consists of apatite ore bodies including apatite, barian celestite, magnetite, hematite, goethite, fluorite, gypsum, phlogopite, carbonate (mostly calcite), pyrite, and monazite-(Ce) $[3,13]$. The chemical composition of the sample was analyzed by X-ray fluorescence (XRF) and summarized in Table 1 . The total level of REOs is approximately $10 \%$. The most abundant REE is Ce, followed by La, Nd, Pr, and Y.

X-ray diffraction (XRD) (D/MAX-2500V/PC, Rigaku, Tokyo, Japan) was used to characterize the mineral phases in the sample. As shown in Figure 1, the main minerals were identified as apatite and silicate minerals. Minor minerals were goethite, hematite, maghemite, quartz, monazite, and so on.

Detailed mineralogical characterization of the ore was conducted by Enkhbayar et al. [14], who found that REEs were mostly associated with fluorapatite and hydroxyapatite. As shown in Figure 2, the apatite grains have hexagonal structures with a layered arrangement of outer crystals grown upon an inner layer of crystals. Electron probe microanalysis revealed that the REE $\left(\mathrm{Ce}_{2} \mathrm{O}_{3}+\mathrm{La}_{2} \mathrm{O}_{3}+\mathrm{Nd}_{2} \mathrm{O}_{3}\right)$ content increases from the center to the edge of the specimen $(9.45 \mathrm{wt} \%$ in $\mathrm{mh} 21,12.51 \mathrm{wt} \%$ in $\mathrm{mh} 23,45.57 \mathrm{wt} \%$ in $\mathrm{mh} 24)$. The Si and Na contents also increased from the center to the edge of the structure. Conversely, the amounts of P and Ca decreased from the center to the edge of the sample. These trends indicate that more REE was substituted for Ca in apatite as the crystals 
grew. Monazite crystals were also found between the two outer layers. Therefore, it can be expected that the leaching rate would initially be high owing to the presence of a high-grade REE layer in the outer rim of the apatite particles and then decrease because monazite is less reactive than apatite [15].

Table 1. X-ray fluorescence (XRF) analysis of the sample.

\begin{tabular}{cccc}
\hline Formula & Concentration (\%) & Formula & Concentration (\%) \\
\hline $\mathrm{CaO}$ & 32.75 & $\mathrm{MgO}$ & 0.53 \\
$\mathrm{Fe}_{2} \mathrm{O}_{3}$ & 22.91 & $\mathrm{SrO}$ & 0.47 \\
$\mathrm{P}_{2} \mathrm{O}_{5}$ & 18.30 & $\mathrm{Na}_{2} \mathrm{O}$ & 0.45 \\
$\mathrm{SiO}_{2}$ & 9.65 & $\mathrm{Pr}_{6} \mathrm{O}_{11}$ & 0.42 \\
$\mathrm{CeO}_{2}$ & 5.80 & $\mathrm{MnO}$ & 0.29 \\
$\mathrm{La}_{2} \mathrm{O}_{3}$ & 3.01 & $\mathrm{Y}_{2} \mathrm{O}_{3}$ & 0.28 \\
$\mathrm{SO}_{3}$ & 1.80 & $\mathrm{~K}_{2} \mathrm{O}$ & 0.25 \\
$\mathrm{Nd}_{2} \mathrm{O}_{3}$ & 1.48 & $\mathrm{ThO}_{2}$ & 0.06 \\
$\mathrm{Al}_{2} \mathrm{O}_{3}$ & 0.87 & $\mathrm{ZnO}$ & 0.05 \\
$\mathrm{TiO}_{2}$ & 0.62 & $\mathrm{CuO}$ & 0.04 \\
\hline
\end{tabular}

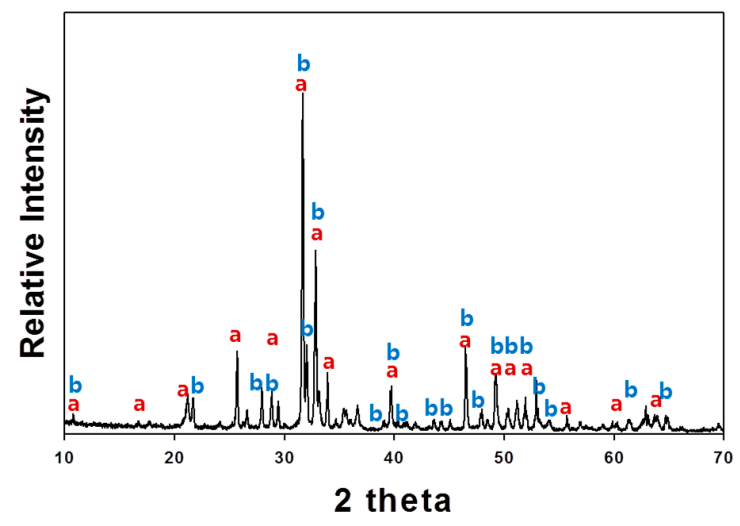

Figure 1. X-ray diffraction (XRD) analysis of the sample. (a) (Ce, La, Nd) hydroxyapatite, fluorapatite, chlorapatite; (b) Nd, Mn silicates.

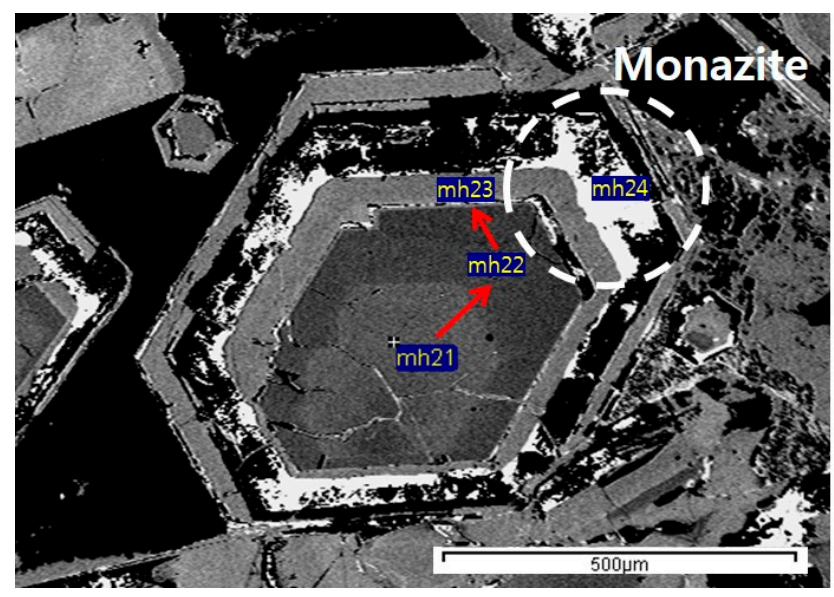

Figure 2. The layered structure of apatite in the sample [14].

\subsection{Experimental Procedure}

Lumps of the ore sample were crushed into smaller pieces with a hammer and were crushed again to $-1 \mathrm{~mm}$ in stages by a jaw crusher and disk mill. They were then ground to $90 \%$ of the passing size of $0.3 \mathrm{~mm}$ using a ball mill. Figure 3 shows the cumulative size distribution of the sample. 


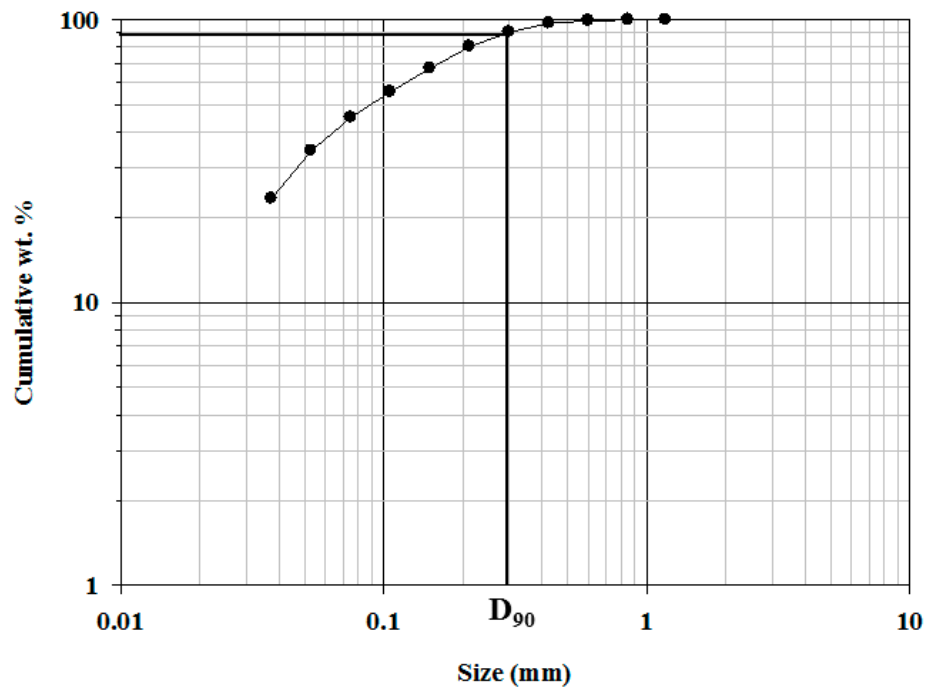

Figure 3. Cumulative size distribution of the sample after crushing and milling.

Because the chemical analysis indicated that the sample contained a large amount of $\mathrm{Fe}(23 \%$ $\mathrm{Fe}_{2} \mathrm{O}_{3}$ ), Fe-bearing minerals were removed from the sample before leaching. A mixture of water and the sample, bearing $10 \mathrm{wt} \%$ solid materials, was prepared and fed through a laboratory wet high-intensity magnetic separator (Eriez Series L-4 Model, Eriez, Erie, PA, USA) operating at 0.2 T. The chemical compositions of the resulting magnetic and nonmagnetic streams were analyzed using XRF.

Basic leaching tests were conducted using sulfuric, hydrochloric, and nitric acids at various concentrations in the ranges of $0.1-13.0 \mathrm{M}$ for sulfuric acid and $0.5-2.0 \mathrm{M}$ for hydrochloric and nitric acid. All of the leaching tests were replicated $4-5$ times, and average values obtained after removing significant outliers were used for analysis. Ten grams of the sample were added to a beaker containing $90 \mathrm{~mL}$ of the acid solution. The slurry was then agitated with an impeller-type stirrer (Daehan Scientific, Wonju, Korea). The slurry samples were collected at regular intervals and the leachate was separated from the solid particles using a filter for lower acid conditions (0.1-2.0 M acids) or a centrifuge for higher acid conditions (5.0-13.0 M acids). The separated leachate was diluted with 1.0 M hydrochloric acid to prevent precipitation of REEs and analyzed using an inductively coupled plasma optical emission spectrometer.

As the leachate contained a considerable amount of $\mathrm{Ca}$, a two-stage leaching method was employed to reduce the amount of $\mathrm{Ca}$ in the final leachate. In stage 1, the sample was preleached using 1.0 M hydrochloric acid to dissolve Ca. In stage 2, the leachate of stage 1 was separated from the residue, and only the solid residue was leached using $2.0 \mathrm{M}$ hydrochloric acid to dissolve the REEs.

\section{Results and Discussion}

\subsection{Magnetic Separation}

Table 2 presents a chemical analysis of both the feed sample and the magnetic and nonmagnetic streams collected from the magnetic separator. The $\mathrm{Fe}_{2} \mathrm{O}_{3}$ content in the nonmagnetic portion decreased significantly from the feed value of $22.9 \%$ to $10.6 \%$. In addition, the REE contents increased correspondingly, as REE-containing apatite is nonmagnetic. Some REEs were lost to the magnetic stream, but the recovery of the REEs in the nonmagnetic stream was still greater than $90 \%$. The $\mathrm{Fe}_{2} \mathrm{O}_{3}$ content of the magnetic stream was very high, and the Fe grade was compatible with typical iron-ore concentrates. Therefore, magnetic separation before leaching offers a potential opportunity not only to reduce Fe impurities in the leachate but also to generate revenue by selling the Fe-rich byproduct to smelters. 
Table 2. Result of XRF analysis of raw sample and magnetically separated samples.

\begin{tabular}{ccccccccc}
\hline \multirow{2}{*}{ Magnetic Intensity } & \multirow{2}{*}{ Sample } & \multirow{2}{*}{ Yield (\%) } & \multicolumn{5}{c}{ Content (wt \%) } \\
\cline { 3 - 9 } & & & $\mathbf{F e}_{\mathbf{2}} \mathbf{O}_{\mathbf{3}}$ & $\mathbf{C e O}_{2}$ & $\mathbf{L a}_{\mathbf{2}} \mathbf{O}_{\mathbf{3}}$ & $\mathbf{N d}_{\mathbf{2}} \mathbf{O}_{\mathbf{3}}$ & $\mathbf{P r}_{\mathbf{6}} \mathbf{O}_{\mathbf{1 1}}$ & $\mathbf{Y}_{\mathbf{2}} \mathbf{O}_{\mathbf{3}}$ \\
\hline- & Raw & 100 & 22.9 & 5.8 & 3.0 & 1.5 & 0.4 & 0.3 \\
\hline \multirow{2}{*}{$0.2 \mathrm{~T}$} & Magnetic & 19.5 & 72.5 & 1.5 & 0.9 & 0.4 & 0.1 & 0.1 \\
& Nonmagnetic & 80.5 & 10.6 & 6.8 & 3.6 & 1.6 & 0.5 & 0.3 \\
\hline \multicolumn{2}{l}{ Recovery to Nonmagnetic (\%) } & & 37.6 & 95.0 & 94.5 & 94.9 & 96.7 & 96.1 \\
\hline
\end{tabular}

\subsection{Effect of Acid Concentration and Type}

Figure 4 shows the change in the leaching efficiency with the sulfuric acid concentration. The experiments were run for $5 \mathrm{~h}$ at $20^{\circ} \mathrm{C}$. At low acid concentrations, the leaching level increased with increasing acid concentration. However, the leaching level decreased at $5.0 \mathrm{M}$. This may result from reprecipitation of REEs via calcium sulfate formation. It is known that calcium sulfate hydrates (gypsum, hemihydrate, and anhydrite) are readily formed wherever calcium and sulfate are present together in aqueous solutions [16].

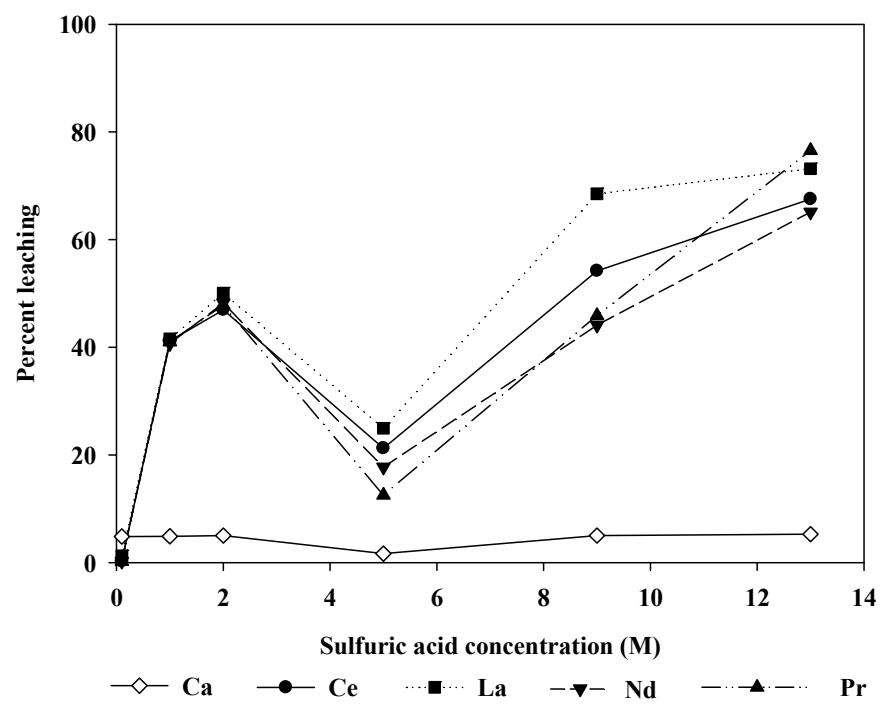

Figure 4. Leaching levels at various initial sulfuric acid concentrations at $20^{\circ} \mathrm{C}$.

Indeed, the $\mathrm{XRD}$ analysis of the residue after leaching shows the presence of gypsum $\left(\mathrm{CaSO}_{4} \cdot 2 \mathrm{H}_{2} \mathrm{O}\right)$ and anhydrite $\left(\mathrm{CaSO}_{4}\right)$ (Figure 5). This residue may contain REEs by isomorphous substitutions for $\mathrm{Ca}^{2+}[8,12,17,18]$, because $\mathrm{Ca}$ and REEs have similar ionic radii. To confirm the existence of REEs in the precipitated gypsum and $\mathrm{CaSO}_{4}$, the leaching residue was dried in atmosphere and was washed with water. The solution phase from this washing was found to contain a significant amount of Ca and REEs $(1.03 \mathrm{~g} / \mathrm{L} \mathrm{Ca}, 0.08 \mathrm{~g} / \mathrm{L} \mathrm{Ce}, 0.03 \mathrm{~g} / \mathrm{L} \mathrm{La}, 0.03 \mathrm{~g} / \mathrm{L} \mathrm{Nd}, 0.02 \mathrm{~g} / \mathrm{L} \mathrm{Pr}$, and $0.009 \mathrm{~g} / \mathrm{L} \mathrm{Y})$, which indicates that the precipitated calcium sulfate hydrates contain REEs by ion substitution. The Ca concentration seems to be higher than the solubility of gypsum $(2.4 \mathrm{~g} / \mathrm{L})$, but the solution may contain free calcium ions and associated calcium sulfate neutral species $\left[\mathrm{CaSO}_{4(\mathrm{aq})}\right]$ dissolved from anhydrite [16,19].

On the other hand, when the concentration of sulfuric acid further increased above $5.0 \mathrm{M}$, the leaching level increased again. It can be postulated that the increase in the acidity may change the solution chemistry to limit the precipitation of calcium sulfate hydrates. To examine more closely the relationship between the leaching patterns and $\mathrm{H}_{2} \mathrm{SO}_{4}$ concentration, the Ca speciation was calculated for the $\mathrm{Ca}-\mathrm{SO}_{4}-\mathrm{H}_{2} \mathrm{O}$ system using thermodynamic data available in the literature [20-22]: 


$$
\begin{aligned}
& \mathrm{HSO}_{4}^{-}+\mathrm{H}_{2} \mathrm{O}=\mathrm{H}_{2} \mathrm{SO}_{4}+\mathrm{OH}^{-} \quad K_{1}=\frac{\left[\mathrm{H}_{2} \mathrm{SO}_{4}\right]\left[\mathrm{OH}^{-}\right]}{\left[\mathrm{HSO}_{4}^{-}\right]}=3.002 \times 10^{-26}, \\
& \mathrm{HSO}_{4}^{-}+\mathrm{OH}^{-}=\mathrm{SO}_{4}^{2-}+\mathrm{H}_{2} \mathrm{O} \quad K_{2}=\frac{\left[\mathrm{SO}_{4}^{2-}\right]}{\left[\mathrm{HSO}_{4}^{-}\right]\left[\mathrm{OH}^{-}\right]}=1.034 \times 10^{12} \text {, } \\
& \mathrm{Ca}^{2+}+\mathrm{OH}^{-}=\mathrm{Ca}(\mathrm{OH})^{+} \quad K_{3}=\frac{\left[\mathrm{Ca}(\mathrm{OH})^{+}\right]}{\left[\mathrm{Ca}^{2+}\right]\left[\mathrm{OH}^{-}\right]}=25.119 \text {, } \\
& \mathrm{Ca}^{2+}+\mathrm{SO}_{4}^{2-}=\mathrm{CaSO}_{4}(\mathrm{aq}) \quad K_{4}=\frac{\left[\mathrm{CaSO}_{4}(\mathrm{aq})\right]}{\left[\mathrm{Ca}^{2+}\right]\left[\mathrm{SO}_{4}^{2-}\right]}=1.157 \times 10^{2}, \\
& \mathrm{Ca}^{2+}+2 \mathrm{OH}^{-}=\mathrm{Ca}(\mathrm{OH})_{2} \quad K_{s 1}=\left[\mathrm{Ca}^{2+}\right]\left[\mathrm{OH}^{-}\right]^{2}=3.890 \times 10^{-6}, \\
& \mathrm{Ca}^{2+}+\mathrm{SO}_{4}^{2-}=\mathrm{CaSO}_{4}(\mathrm{~s}) \quad K_{s 2}=\left[\mathrm{Ca}^{2+}\right]\left[\mathrm{SO}_{4}^{2-}\right]=4.930 \times 10^{-5}, \\
& \mathrm{Ca}^{2+}+\mathrm{SO}_{4}^{2-}+2 \mathrm{H}_{2} \mathrm{O}=\mathrm{CaSO}_{4} \cdot 2 \mathrm{H}_{2} \mathrm{O} K_{s 3}=\left[\mathrm{Ca}^{2+}\right]\left[\mathrm{SO}_{4}^{2-}\right]=3.140 \times 10^{-5} \text {. }
\end{aligned}
$$

There are seven species in the solution: $\mathrm{OH}^{-}, \mathrm{H}_{2} \mathrm{SO}_{4}, \mathrm{HSO}_{4}{ }^{-}, \mathrm{SO}_{4}{ }^{2-}, \mathrm{Ca}^{2+}, \mathrm{Ca}(\mathrm{OH})^{+}, \mathrm{CaSO}_{4(\mathrm{aq})}$. Therefore, three more equations in addition to Equations (1)-(4) are required to calculate the equilibrium composition. Two additional equations used were mass balance equations for Ca species and sulfate species. One additional equation could be the charge balance equation, but in our calculations, the $\mathrm{OH}^{-}$concentrations were assumed to be known and were calculated from the final $\mathrm{pH}$ of the solutions in the actual experiment. The total Ca concentration was assumed to be $0.5 \mathrm{M}$ considering the number of moles of $\mathrm{Ca}$ in the ore. The equilibrium composition was then calculated under different levels of total sulfate concentrations (1.0, 2.0, 5.0, 9.8, and 13.0 M). If the calculated values were greater than any of the $K_{s p}$ values [Equations (5)-(7)], the $\mathrm{Ca}^{2+}$ concentration was recalculated using the Equations (5)-(7) and the calculations were repeated until the calculated values satisfied all conditions. The exact solution was obtained by an iterative method using "Solver" function in MS Excel (Microsoft, Redmond, WA, USA).

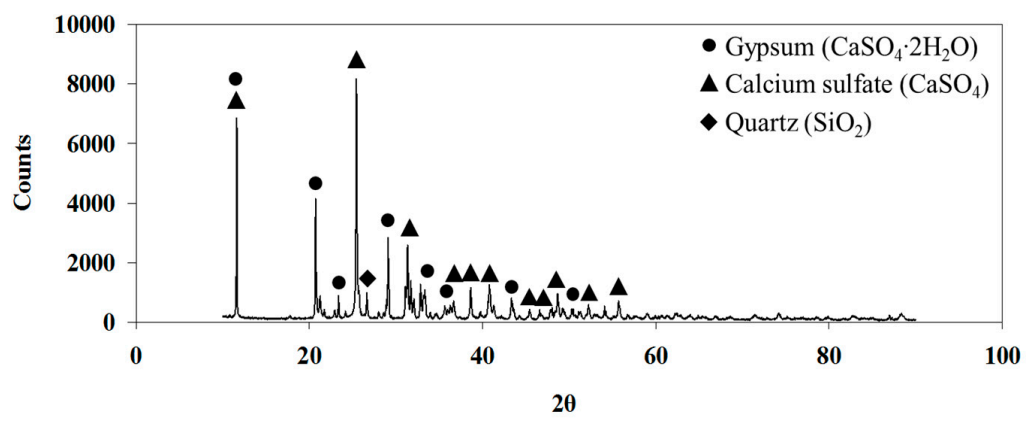

Figure 5. XRD analysis of residue from leaching with 13.0 M sulfuric acid.

Figure 6 shows the calculation results, showing the distribution of Ca species as a function of the initial sulfuric acid concentration. In this highly acidic condition, Ca was present mainly in the form of $\mathrm{Ca}^{2+}$ and $\mathrm{CaSO}_{4(\mathrm{aq})}$. The concentration of $\mathrm{CaSO}_{4(\mathrm{aq})}$ does not change with the sulfuric acid concentration, as the solution become saturated owing to the high concentrations of $\mathrm{Ca}^{2+}$ and $\mathrm{SO}_{4}{ }^{2-}$. On the other hand, the concentration of $\mathrm{Ca}^{2+}$ changes with the sulfuric acid concentration, showing a minimum at $5.0 \mathrm{M}$. The final $\mathrm{pH}$ of the solution decreased initially with increasing the sulfuric acid concentration, but remained the same from 2.0 to $5.0 \mathrm{M}$ of sulfuric acid. However, with more addition of sulfuric acid, the final $\mathrm{pH}$ decreased again, which accompanies the increases in the concentration 
of $\mathrm{Ca}^{2+}$. It indicates that the concentration of $\mathrm{Ca}^{2+}$ species changed in a complicated manner due to the competing balance between the precipitation and dissolution of $\mathrm{Ca}$, which is affected by $\mathrm{H}^{+}$, $\mathrm{SO}_{4}{ }^{2-}$ and $\mathrm{Ca}^{2+}$ in the solution. Accordingly, the total soluble Ca species varies with the sulfuric acid concentration in a pattern very similar to the leaching pattern. This result suggests that sulfuric acid may not be a good leaching agent for this ore, as the side reaction, $\mathrm{Ca}(\mathrm{REE})$ sulfate precipitation, limits the REE leaching level, which did not exceed $80 \%$, even when a large excess of acid (13.0 M) was used.

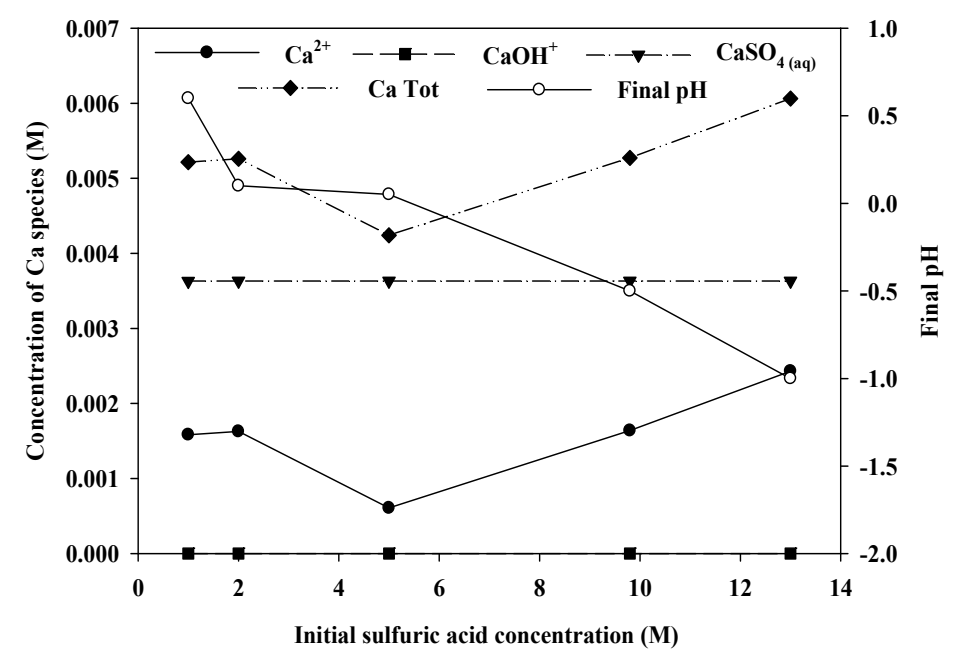

Figure 6. Ca speciation under different initial sulfuric acid concentrations at $25{ }^{\circ} \mathrm{C}, 1 \mathrm{~atm}$. Equilibrium composition calculated by solving Equations (1)-(7).

Figure 7 shows the variation in the leaching levels with the initial concentration of hydrochloric acid. Almost no REEs were leached when the concentration was less than 1.0 M. At higher concentrations of hydrochloric acid, the leaching levels increased sharply. At an acid concentration of 2.0 M, nearly $100 \%$ of the REEs were leached. However, the amount of Ca in the leachate was also very high $(27,480 \mathrm{mg} / \mathrm{L})$, which would undoubtedly cause complications during REE recovery by either precipitation or solvent extraction.

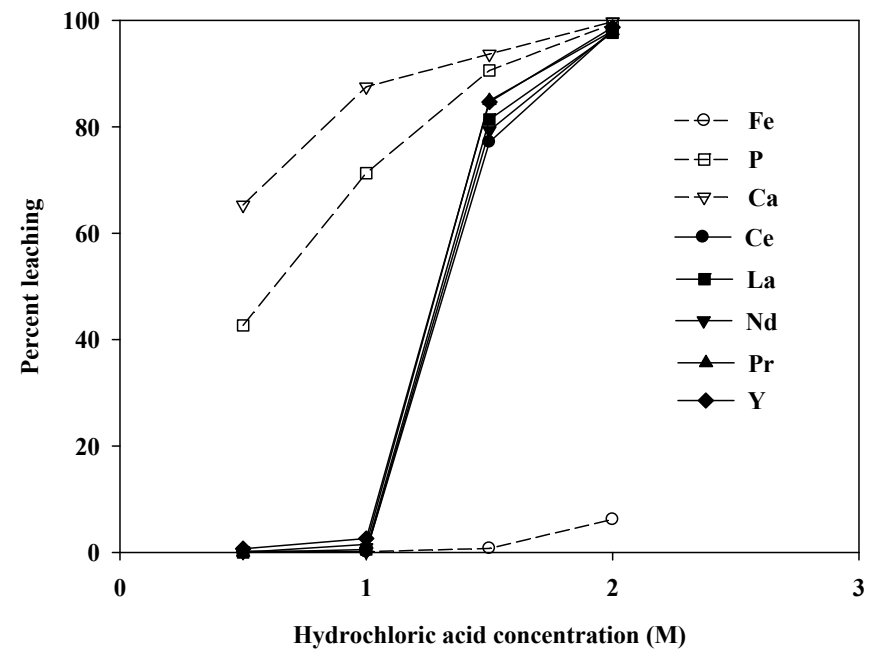

Figure 7. Leaching levels at various initial hydrochloric acid concentrations at $20^{\circ} \mathrm{C}$. Leaching time: $2 \mathrm{~h}$; solid/liquid (S/L) ratio $(w / v):$ 1:9.

Figure 8 shows the change in the leaching levels with time when $2.0 \mathrm{M}$ hydrochloric acid was used as the leaching agent. More than $90 \%$ of the REEs were leached in $10 \mathrm{~min}$. At $1 \mathrm{~h}$, almost $100 \%$ of 
the REEs were leached, and the reaction reached equilibrium in $2 \mathrm{~h}$. It could be noted that the rate of the leaching reaction was quite fast. Thus, it was sufficient to leach the ore at room temperature for a relatively short time.

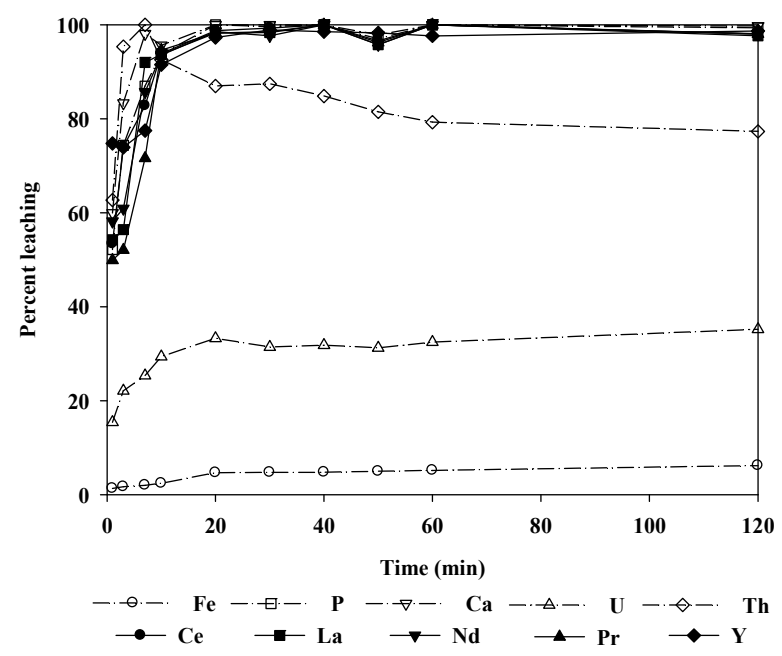

Figure 8. Change in leaching levels with time using hydrochloric acid at $20^{\circ} \mathrm{C}$. Initial acid concentration: 2.0 M; leaching time: $2 \mathrm{~h}$; S/L ratio: 1:9.

Unfortunately, the radioactive elements $\mathrm{U}$ and Th were also leached with the REEs, although the level of radioactivity was statistically insignificant for the ore treated in this study (U: $45 \mathrm{mg} / \mathrm{L}$, Th: $24 \mathrm{mg} / \mathrm{L}$ ). Additionally, the Th leaching level decreased with time because Th precipitated as phosphate in the relatively low $\mathrm{pH}$ region. Thus, the radioactivity of the leaching solution could be further decreased. Note, however, that if the radioactivity of the ore was significant, the removal of radioactive elements from the leachate would require the use of separation techniques such as selective precipitation or the solvent extraction method.

Leaching tests were conducted at elevated temperatures to determine whether the leaching levels and reaction rate could be improved. Because almost $100 \%$ of the REEs were leached using 2.0 $\mathrm{M}$ hydrochloric acid in an hour, tests of the temperature dependence were conducted using $1.0 \mathrm{M}$ hydrochloric acid at 20,50, and $80^{\circ} \mathrm{C}$. As shown in Figure 9, the overall leaching levels for all REEs did not increase significantly; however, other impurity ions ( $\mathrm{Fe}, \mathrm{P}, \mathrm{Ca}$, and $\mathrm{U}$ ) were leached more as the temperature increased. Therefore, it is preferable to operate with a higher concentration of hydrochloric acid at room temperature than to operate at elevated temperatures.

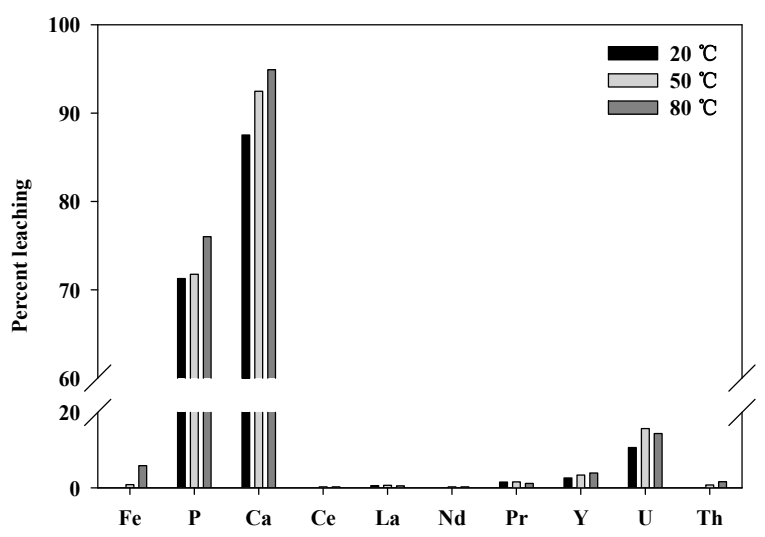

Figure 9. Comparison of final leaching levels using hydrochloric acid at 20,50 and $80{ }^{\circ} \mathrm{C}$. Initial acid concentration: $1.0 \mathrm{M}$; leaching time: $3 \mathrm{~h}$; S/L ratio: 1:9. 
Figure 10 shows the leaching levels at varying concentrations of nitric acid. No REEs, aside from $Y$, were leached at $1.0 \mathrm{M}$, whereas impurities such as $\mathrm{P}$ and $\mathrm{Ca}$ were leached quite well. However, as the acid concentration was increased to $2.0 \mathrm{M}$, almost $100 \%$ of the REEs were leached. These results were similar to the hydrochloric acid case. Because nitric acid is generally more expensive than hydrochloric acid, it was not considered in later sections. Consequently, hydrochloric acid was chosen as the optimum leaching agent for this apatite REE ore, and the effects of other variables on the leaching efficiency were investigated using hydrochloric acid in later experiments.

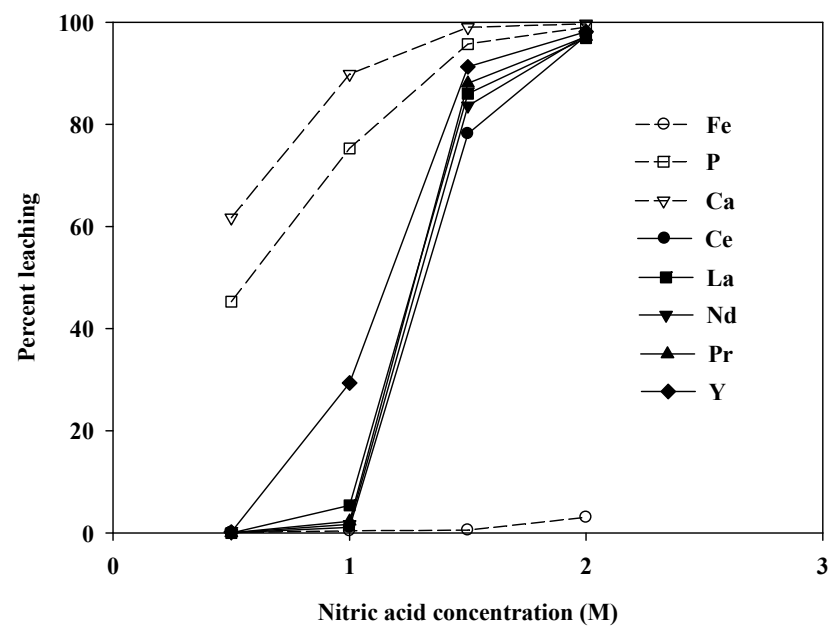

Figure 10. Leaching levels at various initial nitric acid concentrations at $20{ }^{\circ} \mathrm{C}$. Leaching time: $2 \mathrm{~h}$; $\mathrm{S} / \mathrm{L}$ ratio: $1: 9$.

\subsection{Two-Stage Leaching}

As mentioned previously, the leachate obtained using 2.0 M hydrochloric acid contained a significant amount of $\mathrm{Ca}$, as the major mineral phase of the sample is apatite. Therefore, a two-stage leaching process was attempted to reduce the amount of $\mathrm{Ca}$ in the leachate.

\subsubsection{Stage 1 Leaching}

In stage 1, 1.0 M hydrochloric acid was used to dissolve the apatite. Figure 11 shows the change in the leaching levels of $\mathrm{P}$ and $\mathrm{Ca}$ ions together with the REEs over time. Within the first 10 min of leaching, the REE leaching levels were higher than those of $\mathrm{P}$ and $\mathrm{Ca}$. This may result from the mineralogical structure of the ore. As mentioned earlier, the REE concentration was higher at the outer edge of the apatite grains than at the center. The monazite grains, which bore a much higher percentage of REEs, were also present at the surface of the apatite. Conversely, the amounts of P and Ca increase gradually from the edge to the center of the apatite grains. Thus, a high initial leaching level of REEs is expected, as the leaching solution reacts first with the outer layer of the solid particles. After $10 \mathrm{~min}$, the REE levels in the leachate decreased. It seemed that this could be attributed to precipitation of REEs as phosphates.

To analyze the leaching behavior more specifically during stage 1, a thermodynamic analysis was performed to calculate the leaching $\mathrm{pH}$ values for apatite, REE phosphates, and Ca phosphate using thermodynamic data available in the literature [22-27]. It was assumed that the concentration of the substance reaches $1.0 \mathrm{~mol} / \mathrm{L}$ for apatite and $\mathrm{Ca}$ phosphate, and $0.1 \mathrm{~mol} / \mathrm{L}$ for REE phosphates. The leaching $\mathrm{pH}$ values were calculated on the basis of the chemical reactions given in Equations (8)-(10). The results are summarized in Tables 3 and 4. Fluorapatite, hydroxyapatite, and chlorapatite leach at $\mathrm{pH}$ values of 1.0,3.2, and 2.3, respectively. Therefore, in the early stages of leaching with 1.0 M hydrochloric acid, all three forms of apatite could be leached from the ore because the $\mathrm{pH}$ of the acid solution was 0 : 


$$
\begin{gathered}
\mathrm{Ca}_{10}\left(\mathrm{PO}_{4}\right)_{6} \mathrm{X}_{2}+20 \mathrm{H}^{+}=10 \mathrm{Ca}^{2+}+6 \mathrm{H}_{3} \mathrm{PO}_{4}+2 \mathrm{HX}(\mathrm{X}=\mathrm{F}, \mathrm{OH}, \mathrm{Cl}), \\
\mathrm{Ca}_{3}\left(\mathrm{PO}_{4}\right)_{2}+6 \mathrm{H}^{+}=3 \mathrm{Ca}^{2+}+2 \mathrm{H}_{3} \mathrm{PO}_{4} \\
\mathrm{REEPO}_{4}+3 \mathrm{H}^{+}=\mathrm{REE}^{3+}+\mathrm{H}_{3} \mathrm{PO}_{4} .
\end{gathered}
$$

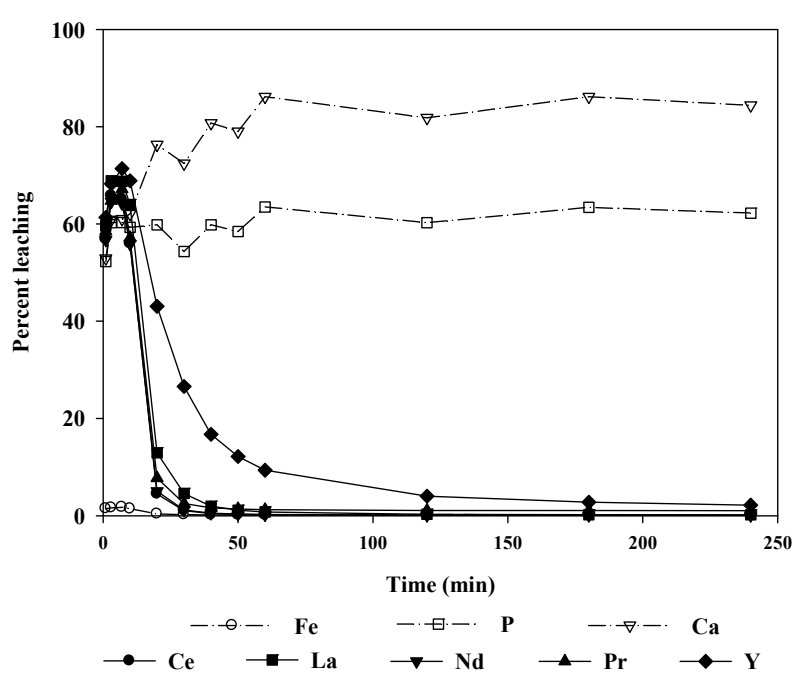

Figure 11. Change in leaching levels over the course of stage 1 using hydrochloric acid at $20^{\circ} \mathrm{C}$. Initial acid concentration: $1.0 \mathrm{M}$; leaching time: $4 \mathrm{~h}$; $\mathrm{S} / \mathrm{L}$ ratio: 1:9.

During leaching, it was found that the $\mathrm{pH}$ increased from 0 to approximately 1.5. In this range, the dissolved REEs and phosphate ions can react to form REE phosphates, as the leaching $\mathrm{pH}$ for REE phosphates is less than or around 0 (Table 4). In contrast, Ca does not precipitate because both apatite and $\mathrm{Ca}$ phosphate are still leachable in this $\mathrm{pH}$ region, as shown in Table 3. Therefore, Ca dissolution continues during this stage, whereas the amount of REEs in the liquid phase decreases as the REE phosphates precipitate.

Table 3. Thermodynamic data and leaching $\mathrm{pH}$ of apatite and calcium phosphate according to Equations (8) and (9), respectively $\left(\Delta \mathrm{G}_{\mathrm{f}}^{\circ}\right.$ of $\left.\mathrm{H}^{+}: 0 \mathrm{~kJ} / \mathrm{mol} ; \mathrm{Ca}^{2+}:-553.58 \mathrm{~kJ} / \mathrm{mol} ; \mathrm{H}_{3} \mathrm{PO}_{4}:-1142.54 \mathrm{~kJ} / \mathrm{mol}\right)$.

\begin{tabular}{ccccc}
\hline \multirow{2}{*}{ Apatite } & \multicolumn{3}{c}{$\Delta \mathbf{G}_{\mathbf{f}}^{\circ} \mathbf{( \mathbf { k J } / \mathbf { m o l } )}$} & \multirow{2}{*}{ Leaching $\mathbf{p H}$} \\
\cline { 2 - 4 } & Apatite & $\mathbf{H X}^{\mathbf{1}}$ & $\Delta \mathbf{G}^{\circ} \mathbf{r x n}$ & \\
\hline $\mathrm{Ca}_{10}\left(\mathrm{PO}_{4}\right)_{6} \mathrm{~F}_{2}$ Fluorapatite & $-12,885.9$ & -296.82 & -98.76 & 1.00 \\
$\mathrm{Ca}_{10}\left(\mathrm{PO}_{4}\right)_{6}(\mathrm{OH})_{2}$ Hydroxyapatite & $-12,503.5$ & -237.18 & -361.93 & 3.24 \\
$\mathrm{Ca}_{10}\left(\mathrm{PO}_{4}\right)_{6} \mathrm{Cl}_{2}$ Chlorapatite & $-12,403.0$ & -131.23 & -250.50 & 2.33 \\
$\mathrm{Ca}_{3}\left(\mathrm{PO}_{4}\right)_{2}$ & -3884.82 & - & -61.00 & 1.84 \\
\hline 1 & $\mathrm{X}=\mathrm{F}, \mathrm{OH}, \mathrm{Cl}$ for fluor, hydroxy and chlorapatite, respectively. \\
\hline
\end{tabular}

Table 4. Thermodynamic data and leaching $\mathrm{pH}$ of REE phosphates according to Equation (10) $\left(\Delta \mathrm{G}_{\mathrm{f}}^{\circ}\right.$ of $\mathrm{H}^{+}: 0 \mathrm{~kJ} / \mathrm{mol} ; \mathrm{H}_{3} \mathrm{PO}_{4}:-1142.54 \mathrm{~kJ} / \mathrm{mol}$ ).

\begin{tabular}{ccccc}
\hline \multirow{2}{*}{ REE Phosphate } & \multicolumn{3}{c}{$\left.\Delta \mathbf{G}_{\mathbf{f}}{ }^{\circ} \mathbf{( k J / m o l}\right)$} & \multirow{2}{*}{ Leaching $\mathbf{~ H ~}$} \\
\cline { 2 - 4 } & $\mathbf{R E E P O}_{\mathbf{4}}$ & $\mathbf{R E E}^{3+}$ & $\Delta \mathbf{G}^{\circ} \mathbf{\text { rxn }}$ & \\
\hline $\mathrm{YPO}_{4}$ & -1846.96 & -686.92 & 17.50 & -0.36 \\
$\mathrm{LaPO}_{4}$ & -1898.43 & -730.46 & 25.43 & -0.82 \\
$\mathrm{CePO}_{4}$ & -1827.32 & -677.33 & 7.45 & 0.23 \\
$\mathrm{PrPO}_{4}$ & -1880.33 & -712.88 & 24.92 & -0.79 \\
$\mathrm{NdPO}_{4}$ & -1870.92 & -704.09 & 24.29 & -0.75 \\
\hline
\end{tabular}


In Figures 7 and 11, it can be noted that the percentage of dissolved $\mathrm{P}$ is always less than that of $\mathrm{Ca}$ for 1.0 M hydrochloric acid. This also implies that the dissolved P is consumed as the REE phosphates form. Otherwise, the leaching levels of P, REEs, and Ca would be similar over time. Table 5 presents the hypothetical P leaching levels if no precipitation occurred. In these calculations, it was assumed that the REEs disappeared from the solution according to the reaction $\mathrm{REE}^{3+}+\mathrm{PO}_{4}^{3-}=\mathrm{REEPO}_{4}$; i.e., moles of phosphate ions and REEs were removed from the solution in a 1:1 ratio as precipitation progressed. When the number of moles of phosphate ions consumed by the precipitation reaction is calculated and added to the experimentally measured phosphate level, the calculated leaching levels of $\mathrm{P}$ are very close to those of Ca throughout the process. This confirms that the REE phosphates precipitate out of the solution during this stage.

Table 5. Comparison of $\mathrm{P}$ and Ca leaching level during stage 1 leaching.

\begin{tabular}{cccc}
\hline \multirow{2}{*}{ Leach Time (min) } & \multicolumn{2}{c}{ P Leaching Level } & \multirow{2}{*}{ Ca Leaching Level } \\
\cline { 2 - 3 } & Actual & Re-Calculated & \\
\hline 1 & 52.25 & 52.26 & 52.93 \\
3 & 60.26 & 60.28 & 60.86 \\
7 & 60.29 & 60.31 & 61.01 \\
10 & 59.29 & 60.23 & 62.07 \\
20 & 59.83 & 74.53 & 76.31 \\
30 & 54.33 & 69.30 & 72.41 \\
40 & 59.83 & 76.87 & 80.74 \\
50 & 58.44 & 75.20 & 79.01 \\
60 & 63.50 & 81.83 & 86.16 \\
120 & 60.24 & 77.70 & 81.80 \\
180 & 63.42 & 81.83 & 86.16 \\
240 & 62.21 & 80.25 & 84.37 \\
\hline
\end{tabular}

Indeed, some REE phosphates were identified by XRD analysis of the residue from stage 1, as shown in Figure 12. This indicated that it would be possible to dissolve Ca and P selectively from the ore while keeping the REEs in the solid residue by using 1.0 M hydrochloric acid for a reasonable leaching time, approximately $3-4 \mathrm{~h}$.

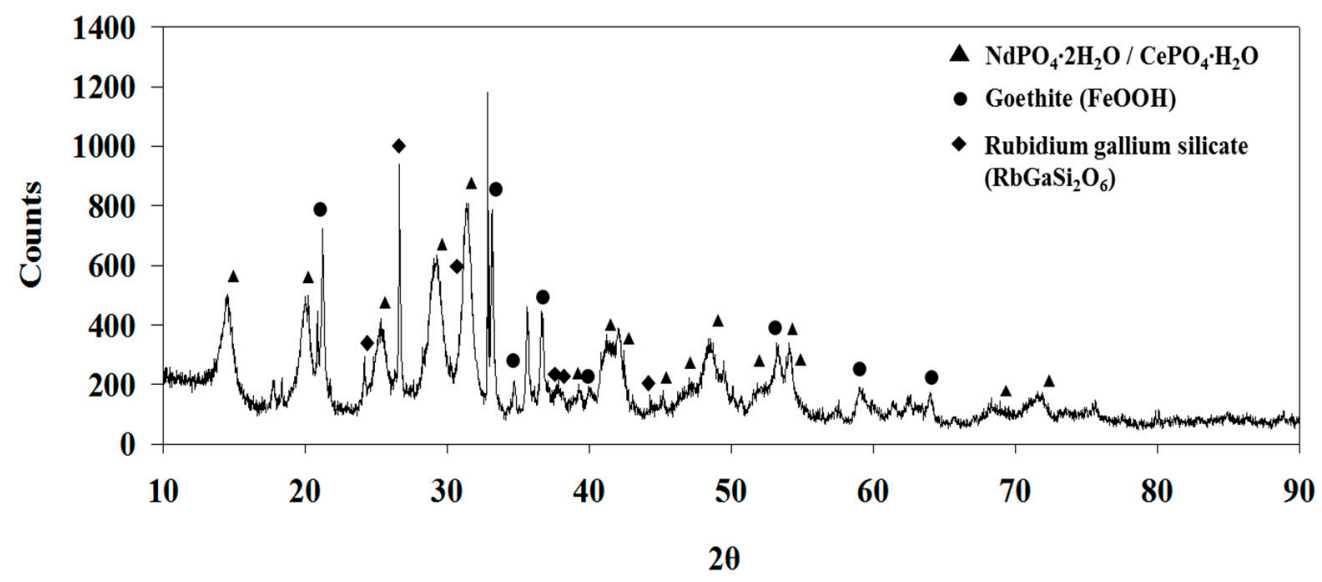

Figure 12. XRD analysis of the residue from stage 1, showing the presence of REE phosphates.

\subsubsection{Stage 2 Leaching}

The solid residue from stage 1 was subjected to stage 2 leaching using $2.0 \mathrm{M}$ hydrochloric acid as a leaching agent. Figure 13 shows that the leaching of REEs reaches nearly $100 \%$ in a short time. Table 6 compares the leaching levels of REEs, calculated as the ratio of the amount of REEs in the leachate 
after 120 min of leaching to that in the raw sample, with those obtained by one-stage leaching under the same conditions. The amounts of the major impurities $(\mathrm{Ca}, \mathrm{P}$, and $\mathrm{Fe})$ in the final leachate are also shown. The leaching levels of the REEs were not affected by the use of two-stage leaching, indicating that only the impurities were selectively leached during the first stage of leaching. As a consequence, the amounts of $\mathrm{Ca}$ and $\mathrm{P}$ in the final leachate were considerably reduced from 27,480 and 11,260 mg/L to 5030 and $4400 \mathrm{mg} / \mathrm{L}$, respectively.

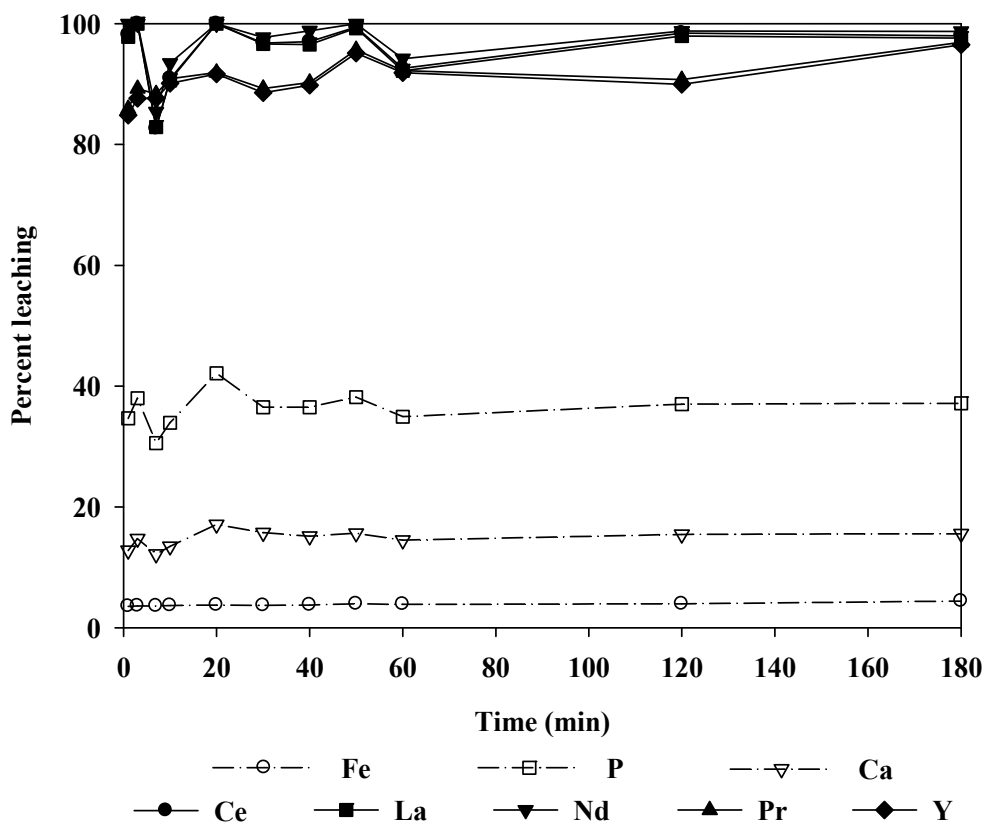

Figure 13. Leaching levels for various elements over the course of stage 2 using hydrochloric acid. Initial acid concentration: $2.0 \mathrm{M}$; leaching time: $3 \mathrm{~h}$; $\mathrm{S} / \mathrm{L}$ ratio: $1: 9$.

Table 6. Comparison of REE leaching levels in the leachate after $120 \mathrm{~min}$ and the amount of some impurities in the final leachate between one and two-stage processes.

\begin{tabular}{|c|c|c|c|c|c|c|c|c|}
\hline \multirow{2}{*}{ Type of Leaching } & \multicolumn{5}{|c|}{ REE Leach Level (\%) } & \multicolumn{3}{|c|}{ Amount of Impurity (mg/L) } \\
\hline & $\mathrm{Ce}$ & La & Nd & $\operatorname{Pr}$ & $\mathbf{Y}$ & $\mathrm{Ca}$ & $\mathbf{P}$ & $\mathbf{F e}$ \\
\hline One-stage & 98.1 & 97.7 & 98.0 & 98.0 & 98.7 & 27,480 & 11,260 & 190 \\
\hline Two-stage & 98.4 & 97.9 & 98.8 & 90.7 & 90.0 & 5030 & 4400 & 147 \\
\hline
\end{tabular}

\subsection{Optimal Processing Route}

On the basis of the experimental results of this study, we propose a route for optimal processing and leaching of REEs from this ore, as shown in Figure 14. In this process, the ore is crushed and ground to $90 \%$ passing $0.3 \mathrm{~mm}$. Then, magnetic separation is applied to separate Fe bearing minerals, which results in $60 \%$ removal of Fe with a 5\%-6\% loss of REEs. The Fe grade of the magnetic product is very high (over $70 \%$ ), so it can be sold to the steel-making industry. The nonmagnetic stream is then subject to a two-stage leaching process. In stage 1, the ore is leached with $1.0 \mathrm{M} \mathrm{HCl}$, where approximately $90 \%$ of the $\mathrm{Ca}$ is removed with no loss of REEs. The residue from stage 1 leaching is then subject to stage 2 leaching with $2.0 \mathrm{M} \mathrm{HCl}$, where most of the REEs are leached out in an hour. The final recovery of REEs after leaching is around $92 \%-94 \%$ for each REE-a considerably higher amount than that yield by other current processing practices. Table 7 summarizes the metallurgical balance of the proposed processing flow. 


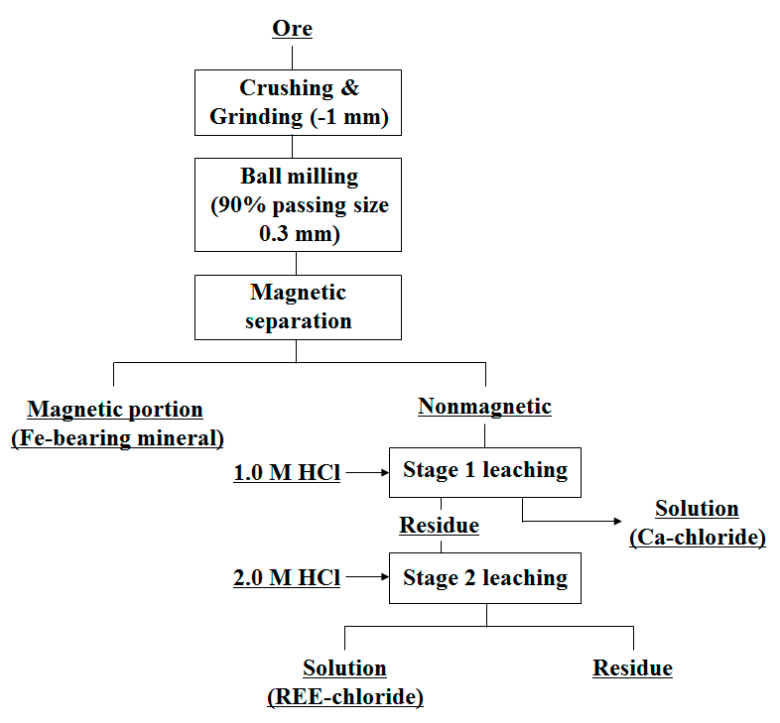

Figure 14. Optimal processing of the ore.

Table 7. Metallurgical balance of the optimal process.

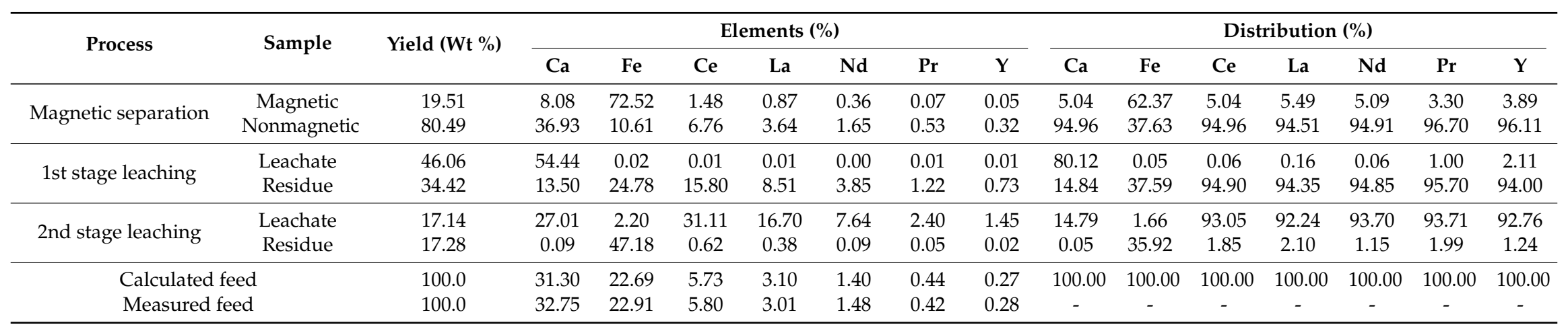




\section{Conclusions}

The REE ore deposit currently under investigation can become a new major source of REEs judging from its magnitude and grade. Furthermore, test results show that this ore can be processed by a rather simple route with a recovery of all REEs of over $90 \%$ REEs. It seems that physical separation of REE-containing minerals may not be easy. However, removal of Fe-bearing minerals before leaching is possible using magnetic separation with minimal loss of REEs. This would reduce the operation cost of the leaching process because much of the acid could be consumed by Fe minerals in the ore. At the same time, additional profit can be realized by the sale of Fe concentrate as the magnetic product has a smelter grade.

Leaching tests reveal that REEs can be effectively extracted using $\mathrm{HCl}$ at ambient temperature and pressure. The $U$ and Th content of the leachate was not at a significant level that demands additional treatment. However, the $\mathrm{Ca}$ level was very high when direct leaching with $\mathrm{HCl}$ was performed. Consequently, a two-stage leaching process was developed. In stage 1, leaching is conducted under a mild condition $(1.0 \mathrm{M} \mathrm{HCl})$ to elute Ca from the ore. In stage 2 leaching, $90 \%-100 \%$ of the REEs were recovered using 2.0 M HCl. The final recovery of REEs after leaching is very high around $92 \%-94 \%$ for each REE-a considerably higher amount than that yield by other current processing practices.

Acknowledgments: This work was supported by a grant from the Korea Institute of Energy Technology Evaluation and Planning (KETEP) funded by the Ministry of Trade, Industry, and Energy (MOTIE) of the Korean government (No. 20122010300041).

Author Contributions: Rina Kim performed the experiments, and analyzed and interpreted the data. Heechan Cho was the Principal Investigator of this work and edited the paper. Kenneth N. Han contributed to interpretation of the data. Kihong Kim and Myoungwook Mun performed magnetic separation tests and helped to analyze the data.

Conflicts of Interest: The authors declare no conflict of interest.

\section{References}

1. Daly, J.C.K. Mongolia's rare earth reserves draw foreign investor interest. Centr. Asia-Caucasus Anal. 2011, 13, 6-8.

2. Altangerel, T. Rare Earth Deposits in Mongolia. Available online: http://criticalmetalsmeeting.com/ download/CM-2013_Finalized_program.pdf (accessed on 30 June 2016).

3. Sanematsu, K.; Kon, Y.; Hirando, H.; Watanabe, Y. Mineralogy and Geochemistry of the Mushgai Kudag REE Deposit, Mongolia. In Geological Society of America Abstracts with Programs; The Geological Society of America: Denver, CO, USA, 2010; Volume 42, p. 335.

4. Chi, R.; Tian, J.; Zhu, G.; Wu, Y.; Li, S.; Wang, C.; Zhou, Z.A. Kinetics of rare earth leaching from a mangnese-removed weathered rare-earth mud in hydrochloric acid solutions. Separ. Sci. Technol. 2006, 41, 1099-1113. [CrossRef]

5. Zielinski, S.; Szczepanik, A.; Buca, M. Recovery of lanthanides from Kola Apatite in phosphoric acid manufacture. J. Chem. Technol. Biotechnol. 1993, 56, 355-360. [CrossRef]

6. Jones, A.P.; Wall, F.; Williams, C.T. Rare Earth Minerals-Chemistry, Origin and Ore Deposits; Chapman \& Hall: London, UK, 1996.

7. Martin, P.; Carlot, G.; Chevarier, A.; Den-Auwer, C.; Panczer, G. Mechanisms involved in thermal diffusion of rare earth elements in apatite. J. Nucl. Mater. 1999, 275, 268-276. [CrossRef]

8. Jorjani, E.; Bagherieh, A.H.; Chelgani, S.C. Rare earth elements leaching from Chadormalu apatite concentrate: Laboratory studies and regression predictions. Korean J. Chem. Eng. 2011, 28, 557-562. [CrossRef]

9. Aly, M.M.; Mohammed, N.A. Recovery of lanthanides from Abu Tartur Phosphate Rock, Egypt. Hydrometallurgy 1999, 52, 199-206. [CrossRef]

10. Sandström, Å.; Fredriksson, A. Apatite for extraction-Leaching of Kiirunavaara Apatite for simultaneous production of fertilizers and REE. In Proceedings of the 26th International Mineral Processing Congress, IMPC 2012: Innovative Processing for Sustainable Growth, New Delhi, India, 24-28 September 2012; pp. 4707-4714.

11. Pereira, F.; Bilal, E. Phosphoric acid extraction and rare earth recovery from apatites of the Brazilian Phosphatic Ores. Romanian J. Mineral. Depos. 2012, 85, 49-52. 
12. Habashi, F. The recovery of the lanthanides from Phosphate Rock. J. Chem. Technol. Biotechnol. Chem. Technol. 1985, 35, 5-14. [CrossRef]

13. Garamjav, D.; Jargalan, S. Introduction to REE metallogeny of the Mongolia. Mong. Geosci. 2009, 35, 73-76.

14. Enkhbayar, D.; Seo, J.; Choi, S.; Lee, Y.; Batmunkh, E. Mineral chemistry of REE-rich apatite and sulfur-rich monazite from the Mushgai Khudag, Alkaline Volcanic-Plutonic Complex, South Mongolia. Int. J. Geosci. 2016, 7, 20-31. [CrossRef]

15. Peelman, S.; Sun, Z.H.I.; Sietsma, J.; Yang, Y. Hydrometallurgical extraction of rare earth elements from low grade mine tailings. In Rare Metal Technology 2016; Alan, S., Kim, H., Neelameggham, N.R., Ouchi, T., Oosterhof, H., Eds.; John Wiley \& Sons, Inc.: Hoboken, NJ, USA, 2016.

16. Azimi, G.; Papangelakis, V.G. The Solubility of gypsum and anhydrite in simulated laterite pressure acid leach solutions up to $250^{\circ} \mathrm{C}$. Hydrometallurgy 2010, 102, 1-13. [CrossRef]

17. Todorovsky, D.S.; Milanova, M.M.; Minkova, N.L.; Balarev, C. Solubility of some lanthanide sulfate in polycomponent systems containing $\mathrm{H}_{2} \mathrm{SO}_{4}$. Monatsh. Chem. 1993, 124, 673-679. [CrossRef]

18. Wang, L.; Long, Z.; Huang, X.; Yu, Y.; Cui, D.; Zhang, G. Recovery of rare earths from wet-process phosphoric acid. Hydrometallurgy 2010, 101, 41-47. [CrossRef]

19. Gangolli, S. The Dictionary of Substances and Their Effects: C; Royal Society of Chemistry: London, UK, 1999.

20. Martell, E.A.; Smith, R.M. Critical Stability Constants Volume 4; Plenum Press: New York, NY, USA, 1982.

21. Lide, D.R. CRC Handbook of Chemistry and Physics, 83rd ed.; CRC Press: Cleveland, OH, USA, 2002.

22. Kim, E.; Osseo-Asare, K. Aqueous stability of Thorium and rare earth metals in monazite hydrometallurgy: Eh-pH diagrams for the systems Th-, Ce-, La-, Nd- $\left(\mathrm{PO}_{4}\right)-\left(\mathrm{SO}_{4}\right)-\mathrm{H}_{2} \mathrm{O}$ at $25^{\circ} \mathrm{C}$. Hydrometallurgy 2012, 113-114, 67-78. [CrossRef]

23. Firsching, F.H.; Brune, S.N. Solubility products of the trivalent rare-earth phosphates. J. Chem. Eng. Data 1991, 36, 93-95. [CrossRef]

24. Oxtoby, D.W.; Gillis, H.P.; Nachtrieb, N.H. Principles of Modern Chemistry, 5th ed.; Thomson: Pacific Grove, CA, USA, 2002.

25. La Iglesia, A. Estimating the thermodynamic properties of phosphate minerals at high and low temperature from the sum of constituent units. Estud. Geol. 2009, 65, 109-119. [CrossRef]

26. Han, K.N.; Kellar, J.J.; Cross, W.M.; Safarzadeh, S. Opportunities and challenges for treating rare-earth elements. Geosyst. Eng. 2014, 17, 178-194. [CrossRef]

27. Kim, R.; Cho, H.C.; Han, K.N. Behavior of anions in association with metal ions under hydrometallurgical environments Part $\mathrm{I}-\mathrm{OH}^{-}$effect on various cations. Miner. Metall. Proc. 2014, 31, 40-47.

(c) 2016 by the authors; licensee MDPI, Basel, Switzerland. This article is an open access article distributed under the terms and conditions of the Creative Commons Attribution (CC-BY) license (http://creativecommons.org/licenses/by/4.0/). 